\title{
ІНТЕРФЕРЕНЦІЙНІ ГРАМАТИЧНІ ПОМИЛКИ В ПИСЬМОВОМУ ТА УСНОМУ МОВЛЕННІ СТУДЕНТІВ-ФІЛОЛОГІВ У ПРОЦЕСІ ВИВЧЕННЯ НІМЕЦЬКОЇ МОВИ ЯК ДРУГОЇ ІНОЗЕМНОЇ
}

\author{
Лях О. В. \\ кандидат педагогічних наук, \\ дочент кафедри германської та слов'янської філології \\ Донбаський державний педагогічний університет \\ вул. Генерала Батюка, 19, Слов'янськ, Донеиька область, Украӥна \\ orcid.org/0000-0001-5173-1768 \\ ksana.lyakh88@gmail.com
}

\author{
Ключові слова: \\ інтерференичійні помилки, \\ граматичні помилки, \\ іноземна мова, німецька мова, \\ відмінності.
}

Статтю присвячено проблемі інтерференційних граматичних помилок у письмовому та усному мовленні студентів філологічного факультету в процесі вивчення німецької мови як другої іноземної після англійської. Помилки є невід'ємною частиною опанування нового навчального матеріалу. Причиною інтерференційних помилок $є$ різниця у фонетиці, граматиці і лексиці мов. Доведено, що інтерференційні помилки $є$ природнім наслідком змішування двох або більше мов. Вивчаючи нову мову, студенти автоматично переносять знання рідної мови i/aбо вже відомої в іноземну, що призводить до виникнення помилок.

Основу досліджень інтерференції двох і більше мов було закладено ще у другій половині XX ст. На сучасному етапі розвитку лінгвістики дослідники вивчають інтерференційні процеси в опануванні граматики, лексики або фонетичної системи нової мови (англійська, німецька, французька, іспанська та ін.) під впливом або тільки рідної мови, або рідної і однієї з іноземних мов.

Типологія студентських граматичних помилок під час опанування німецької мови базується на різниці у порядку слів у реченні, обов'язковій наявності дієслова в реченні, вживанні артиклів, неспівпадінні граматичного роду іменників, невідповідності зворотних дієслів, відмінностях між безособовими реченнями, суттєвому неспівпадінні граматичного керування німецьких і українських прийменників, а також ïx багатозначності. Для того щоб мінімізувати або взагалі позбавитися таких помилок, необхідне чітке вивчення правил та виконання великої кількості різноманітних вправ.

Зазначено, що не тільки різниця у мовах, що їх знає людина, може впливати на вивчення нової мови. Схожість певних аспектів мов може значною мірою допомагати в опануванні іноземної мови. 


\title{
INTERFERENCE GRAMMATICAL MISTAKES IN WRITTEN AND ORAL SPEECH OF THE STUDENTS OF THE PHILOLOGICAL DEPARTMENT IN THE PROCESS OF STUDYING GERMAN, AS THE SECOND FOREIGN LANGUAGE
}

\author{
Liakh O. V. \\ PhD in Pedagogy, \\ Associate Professor at the Department of German and Slavonic Linguistics \\ Donbas State Pedagogical University \\ Heneral Batiuk str., 19, Sloviansk, Donetsk region, Ukraine \\ orcid.org/0000-0001-5173-1768 \\ ksana.lyakh88@gmail.com
}

Key words: interference mistakes, grammatical mistakes, foreign language, the German language, differences.

\begin{abstract}
The article is devoted to the problem of interference grammatical mistakes in written and oral speech of students of the philological department in the process of learning German as a second foreign language, after English. Mistakes are an integral part of acquiring knowledge and mastering new skills. The cause of interference mistakes is the difference in phonetics, grammar and vocabulary of the languages. It is proved that interference mistakes are natural consequence of mixing two or more languages. While learning a new language, students automatically transfer knowledge of their native language and/or already known one to a foreign language, which causes mistakes.

The basis of the research of the interference of two or more languages was laid in the second half of the twentieth century. Nowadays, researchers study interference processes in mastering the grammar, vocabulary or phonetic system of a new language (English, German, French, Spanish, etc.) under the influence of the native language only or native and one of the foreign languages. The student grammatical mistakes in the process of mastering the German language is caused by the difference in word order in the sentence, the mandatory presence of verbs in the sentence, the use of articles, differences between grammatical gender of nouns, inconsistency of reflexive verbs, differences between impersonal sentences, differences between Ukrainian and German prepositions, as well as their polysemanticism. In order to minimize or even get rid of such mistakes, we consider it necessary to study the rules and do a large number of different exercises.

It is noted that not only the differences in languages that a person knows can affect the learning of a new language. The similarity of certain aspects of languages can greatly help in mastering a foreign language.
\end{abstract}

Постановка проблеми. Добре відомо, що під час вивчення іноземної мови відбувається частковий перенос знань із рідної мови в іноземну, що доволі часто сприяє виникненню помилок у мовленні. Причиною цього є відмінності у фонетиці, граматиці (морфології та синтаксисі) і лексиці двох мов.

Основу досліджень інтерференції двох і більше мов було закладено ще у другій половині XX ст. лінгвістами У. Вайнрайх [1], Н. Мечковською [2], А. Реформатським [5], С. Сорокіною [7]. На сучасному етапі розвитку лінгвістики дослідники вивчають інтерференційні процеси в опануванні граматики, лексики або фонетичної системи нової мови (англійська, німецька, французька, іспанська та ін.) під впливом або тільки рідної мови, або рідної і однієї з іноземних мов. Так, інтерференційні процеси в навчанні граматики англійської та німецької мов висвітлюють В. Миськів [3], Л. Морська [4], Л. Семенюк [6] та ін.

Метою статті $є$ вивчення випадків та причин інтерференції в усному та письмовому мовленні студентів-філологів у процесі вивчення німецької мови як другої іноземної (після англійської). Стаття покликана порівняти граматичні аспекти трьох мов (рідної, першої іноземної (англійської) та німецької (як другої іноземної)) для виявлення причин помилок, що їх роблять студенти, які спричинені відмінностями граматичних структур цих мов. 
Виклад основного матеріалу дослідження. Інтерференцію У. Вайнрайх визначив як «випадки відхилення від норм будь-якої з мов, які відбуваються в мові двомовних у результаті того, що вони знають більше мов, ніж одну, тобто внаслідок мовного контакту» $[1$, с. 22$]$.

Н. Мечковська називає інтерференцією помилки в мовленні іноземною мовою, викликані впливом системи рідної мови [2, с. 8]. В.А. Виноградов стверджує, що інтерференція - взаємодія мовних систем в умовах двомовності, що складається або за мовного контакту, або за індивідуального засвоєння нерідної мови, а відхилення від норми і системи нерідної мови, викликані впливом рідної, лінгвіст називає виразом процесу інтерференції [5, с. 197].

Основою дослідження стали письмові (самостійні роботи, домашні вправи, твори, записи на заняттях) роботи та усні висловлювання студентів філологічного факультету ДВНЗ «Донбаський державний педагогічний університет», які вивчають німецьку мову як другу іноземну (після англійської). Отже, у нашому дослідженні контактують три мови: українська, англійська як перша іноземна та німецька як друга іноземна. Саме визначити вплив перших двох мов на процес опанування третьої (німецької), а також на характер помилок, спричинених відмінністю трьох мов, ми намагалися у нашому дослідженні.

Аналіз помилок у письмових роботах та усних висловлюваннях показав, які ж саме відмінності двох мов спричиняють помилки, що найчастіше допускають студенти:

1) Необов'язкова присутність дієслова-зв'язки в українському реченні i, як наслідок, його упускання у німецькому реченні (Ich Student. Manchmal sie sehr müde).

2) Різниця в порядку слів у реченні української, англійської та німецької мов. Якщо порядок слів в українському реченні $€$ довільним, то в німецькому реченні він суворо регламентований правилами граматики: простий присудок повинен займати друге місце в розповідному реченні, складений присудок займає друге та останнє місця в розповідному реченні, наприклад Ich treffe hier oft Bekannte; An diesem Tisch ist der Platz meines Freundes. Wir können das machen. Але, якщо ми говоримо про складнопідрядне речення, то присудок у другорядному реченні завжди стоїть у кінці речення (Ich kann nicht genau sagen, wann die Versammlung stattfindet). Звикнувши до правил рідної мови, а також до порядку слів в англійському реченні, студенти часто міняють порядок слів у німецькому реченні, що, можливо, i не призводить до непорозуміння, але є грубим порушенням правил іноземної мови: Ich habe gearbeitet hier drei Jahre. Er kann helfen Ihnen bei der Übersetzung. Am Ende des Semesters werden durchgeführt Kontrollarbeiten.

3) Велика кількість труднощів, а з ними і помилок, виникає під час передачі безособових форм. В українській мові в безособовому реченні відсутній присудок (Зима. Тихо. Тут не можна фотографувати), чого не можна допустити в німецькій мові. Безособові форми в німецькій мові можна виразити за допомогою займенників еs та man (Es ist Winter. Es ist ruhig. Man darf hier nicht fotografieren), які студенти забувають уживати на початковому етапі вивчення німецької мови (Winter. Ruhig).

4) Відсутність в українській мові такої частини мови, як артикль, є причиною того, що студенти дуже часто упускають його в німецькому мовленні (Es ist Gebäude. Hund meines Freundes spielt mit Katzen). До того ж артикль у німецькій мові на відміну від англійської ще й змінюється за родами, числами та відмінками, що часто призводить до плутанини у формах.

5) Неспівпадіння кількості відмінків в українській та німецькій мовах: сім в українській проти чотирьох у німецькій мові. У студентів на початковому етапі вивчення німецької мови виникає нерозуміння та плутанина у вживанні відмінків, що часто призводить у тому числі й до упускання артиклів (Wir fuhren mit Bus).

6) Неспівпадіння граматичного роду в українській та німецькій мовах (icnum (ч.p.) - die Prüfung (ж.р.), дівчинка (ж.р.) - das Mädchen (c.p.), осінь (ж.p.) - der Herbst (ч.p.)), що призводить до помилок типу Die Mädchen liest gern. Наслідком різниці родів іменників у двох мовах $\epsilon$ заміна іменників не тими особистими займенниками: Das Mädchen liest ein Buch. Sie ist interessant. Сдиним виходом для уникнення такого роду помилок $\epsilon$ вивчення всіх іменників відразу 3 артиклями та суворий контроль уживання артиклів на початковому етапі опанування мови.

7) Різноманіття в утворенні множини іменників викликають труднощі в учнів. На відміну від української мови, де для утворення множини додається закінчення $-u$ або $-a$ та іноді змінюється коренева голосна, а в англійській мові до всіх іменників додається закінчення $-s$ окрім пари десятків винятків, у німецькій мові утворення множини відбувається за сімома типами, у кожному 3 яких використовується своє закінчення та може додаватися умлаут. Так, у письмовому на усному мовленні студентів були виявлені такі випадки неправильного утворення множини (що виражалося у використанні неправильного закінчення та упущення умлауту): Schülern, Stuhle, Vogeln, Kindern, Arzte, Balle.

8) Окрема група помилок, що їх студенти допускають у німецькій мові, пов'язана з такою 
частиною мови, як дієслово. У німецькій мові, як і в українській, є така група дієслів, як зворотні дієслова. Труднощі виникають через те, що дієслова 3 відповідним значенням в українській мові не $\epsilon$ зворотними (наприклад, Ich erhole mich am Wochenende; Er setzt sich auf den $S t u h l)$. Граматичні помилки, зумовлені впливом рідної мови на засвоєння іноземної, виникають і якщо в українській мові дієслово зворотне, а в німецькій - ні. Наприклад: Ти гарно вчишся? - Lernst du gut? Відповідно, студенти упускають або, навпаки, додають зворотний займенник туди, де він непотрібний (Ich erinnere nicht. Sie bewundern sich).

9) Значні труднощі виникають під час вивчення теми керування дієсловами, яке не завжди збігається в українській та німецькій мовах, наприклад: Ich gratuliere dir zu dem Fest (а не mit dem Fest); Sie ist an diesem Unfall schuld (а не in diesen Unfall). Через семантичну невідповідність багатьох німецьких та українських прийменників виникають інтерференційні помилки в таких реченнях, як Wir fahren nach Lviv (а не in Lviv).

10) Багатозначність німецьких прийменників (наприклад, прийменник in за значенням відповідає українським прийменникам «в», «до», «через», тому виникають помилки на кшталт Ich studiere in der Uni. А український прийменник «на» може перекладатися як in, nach, an, auf, zu).

Треба зазначити, що не лише різниця у мовах, що їх знає людина, може впливати на вивчення нової мови. Схожість певних аспектів мов може значною мірою допомагати в опануванні іно- земної мови. Так, вивчаючи німецьку мову після англійської, студентам набагато легше опанувати систему граматичних часів, бо в українській мові їх лише три проти дванадцяти в англійській та шести в німецькій. Також, уже знаючи граматику англійської мови, студентам легше звикнути до чіткого порядку слів у німецькій мові та до побудови безособових речень.

Висновки і перспективи подальших розробок у цьому напрямі. Помилки є невід'ємною частиною процесу оволодіння іноземною мовою. Інтерференційні помилки свідчать про перенос наявних знань студента 3 однісї або більше мов у нову для нього мову. Основні помилки студентів, які вивчають німецьку мову як другу іноземну, пов'язані з порядком слів у реченні, обов'язковою наявністю дієслова в реченні, уживанням артиклів, неспівпадінні граматичного роду іменників, невідповідністю зворотних дієслів, відмінностями між безособовими реченнями, суттєвим неспівпадінням граматичного керування німецькими й українськими прийменниками, а також їх багатозначністю. Для того щоб мінімізувати або взагалі позбавитися таких помилок, необхідне чітке вивчення правил та виконання великої кількості різноманітних вправ.

Перспектива подальших досліджень проблеми інтерференційних помилок полягає у порівнянні трьох і більше мов під час вивчення другої іноземної для виявлення відмінностей та схожих рис у граматиці, лексиці та фонетиці цих мов для попередження явища інтерференційних помилок у студентів.

\section{ЛIТЕРАТУРА}

1. Вайнрайх У. Языковые контакты. Киев : Вища школа, 1979. 263 с.

2. Мечковская Н.Б. Социальная лингвистика. Москва : Аспект-Пресс, 2000. 207 с.

3. Миськів В.А. Прояв граматичної інтерференції у процесі вивчення англійської мови як другої іноземної. Науковий вісник Ужгородського наиіонального університету. Серія «Педагогіка. Сойіальна робота». 2014. Вип. 31. С. 101-103.

4. Морська Л.І. Інтерференційні процеси в навчанні граматики англійської та німецької мов майбутніх філологів. Наукові записки Тернопільського національного педагогічного університету імені Володимира Гнатюка. Серія «Педагогіка». 2014. № 3. С. 130-134.

5. Реформатский А.А. Фонологические этюды. Москва : Наука, 1975. 157 с.

6. Семенюк Л.Й. Міжмовна інтерференція та шляхи їі подолання при вивченні другої іноземної мови. Наукові записки Національного університету «Острозька академія». Серія «Філологічна». 2015. Вип. 55. С. 233-235.

7. Сорокина С.С. Пути преодоления и предупреждения грамматической интерференции синтаксических подтипов в немецкой речи студентов I курса языковых факультетов (на материале подтипа управления) : автореф. дис. ... канд. пед. наук. Ленинград, 1971. 26 с. 


\section{REFERENCES}

1. Vaynrayh U. (1979) Yazyikovyie kontaktyi [Language contacts]. Kiev: Vischa shkola. 263 p. [in Russian].

2. Mechkovskaya N.B. (2000) Sotsialnayalingvistika [Social linguistics]. M.:Aspekt-Press. 207p. [in Russian].

3. Myskiv, V.A. (2014) Proiav hramatychnoi interfentsii u protsesi vyvchennia anhliiskoi movy yak druhoi inozemnoi [Manifestation of grammatical interference in the process of learning English as a second foreign language]. Naukovyi visnyk Uzhhorodskoho natsionalnoho universytetu. Seriia: Pedahohika. Sotsialna robota. Uzhhorod: Hoverla. Vol. 31. P. 101-103. [in Ukrainian].

4. Morska L.I. (2014) Interferentsiini protsesy v navchanni hramatyky anhliiskoi ta nimetskoi mov maibutnikh filolohiv [Interference processes in teaching grammar of English and German to future philologists]. Naukovi zapysky Ternopilskoho natsionalnoho pedahohichnoho universytetu imeni Volodymyra Hnatiuka. Seriia: Pedahohika. Vol. 3. P. 130-134. [in Ukrainian].

5. Reformatskiy A.A. (1975) Fonologicheskie etyudyi [Phonological studies]. M.: Nauka. 157 p. [in Russian].

6. Semeniuk L.Y. (2015) Mizhmovna interferentsiia ta shliakhy yii podolannia pry vyvchenni druhoi inozemnoi movy [Interlingual interference and ways to overcome it while learning a second foreign language]. Naukovi zapysky Natsionalnoho universytetu "Ostrozka akademiia". Seriia : Filolohichna. Vol.. 55. P. 233-235. [in Ukrainian].

7. Sorokina S.S. (1971) Puti preodoleniya i preduprezhdeniya grammaticheskoy interferentsii sintaksicheskih podtipov v nemetskoy rechi studentov 1 kursa yazyikovyih fakultetov (na materiale podtipa upravleniya) [Ways to overcome and prevent grammatical interference of syntactic subtypes in German speech of the 1st year students of language departments (based on the material of the control subtype)]. Extended abstract of Doctor's thesis (Theory of education). L., 26 p. [in Russian]. 